\title{
The Concept of the State in International Relations
}

\author{
Philosophy, Sovereignty, \\ Cosmopolitanism
}

\author{
Edited by Robert Schuett and \\ Peter M. R. Stirk
}

EDINBURGH

University Press 
(C) editorial matter and organisation Robert Schuett and Peter M. R. Stirk, 2015 (C) the chapters their several authors, 2015

Edinburgh University Press Ltd

The Tun - Holyrood Road

12 (2f) Jackson's Entry

Edinburgh EH8 8PJ

www.euppublishing.com

Typeset in 11/14 Sabon by

Servis Filmsetting Ltd, Stockport, Cheshire, and printed and bound in Great Britain by

CPI Group (UK) Ltd, Croydon CR0 4YY

A CIP record for this book is available from the British Library

ISBN 9780748693627 (hardback)

ISBN 9780748693634 (webready PDF)

ISBN 9781474405058 (epub)

The right of the contributors to be identified as authors of this work has been asserted in accordance with the Copyright, Designs and Patents Act 1988 and the Copyright and Related Rights Regulations 2003 (SI No. 2498). 